\title{
Histopathological Pattern of Childhood Solid Tumours in Ilorin: A 28-Year Retrospective Review
}

\author{
Omotayo $\mathrm{Ja}^{1}$, Duduyemi $\mathrm{Bm}^{2, *}$, Buhari $\mathrm{Mo}^{3}$, Anjorin $\mathrm{As}^{3}$ \\ ${ }^{1}$ Department of Pathology, Federal Medical Centre, Owo, Nigeria \\ ${ }^{2}$ Department of Anatomic Pathology, Ekiti State University, Ado-Ekiti, Nigeria \\ ${ }^{3}$ Department of Histopathology, University of Ilorin, Ilorin, Nigeria \\ *Corresponding author: babsdudu@yahoo.com
}

Received August 12, 2013; Revised October 16, 2013; Accepted November 29, 2013

\begin{abstract}
Background: Cancers and other non-communicable diseases were thought to be unimportant public health problems in developing countries because of the overwhelmingly high prevalence of communicable diseases. However, with improved health care facilities and extensive national immunization programmes, coupled with generally improving socio-economic status, malignant diseases are beginning to account for a significant percentage of childhood morbidity and mortality. The study aims to determine the morphological pattern, burden and demographic characteristics of paediatric solid malignancies seen at the University of Ilorin Teaching Hospital between January 1979 and December 2006. Methodology: The demographic characteristics of all cases of malignant solid neoplasms seen in children between the ages of 0 and 15 years were retrieved from the archives and recorded. The histopathological, cytological and the post-mortem slides of the recorded cases were retrieved and reviewed. Special staining techniques were employed where necessary. Results: Three hundred and twenty four cases of childhood solid malignant neoplasms were diagnosed over the study period. The prevalence of childhood malignant solid tumours in Ilorin is 311 per million children. The commonest tumour in this study is lymphoma representing $55.56 \%$ of total paediatric malignant solid neoplasms seen. Burkitt's lymphoma constituted the largest single entity ( $80 \%$ of all lymphomas). This was followed by nephroblastoma, retinoblastoma and bone tumours which accounted for $8.33 \%, 7.72 \%$ and $4.63 \%$ respectively. Intracranial tumours were relatively rare. Conclusion: The pattern of paediatric malignant solid neoplasms seen in Ilorin is similar to what obtains in other parts of Nigeria and African countries. Burkitt's Lymphoma is the commonest childhood malignancy in this study. Nephroblastoma is the second commonest childhood malignant solid neoplasm in Ilorin as against what was observed in other centres such as Ibadan, Ife and Jos where retinoblastoma is the second commonest after lymphoma.
\end{abstract}

Keywords: childhood, histopathological, cytology, malignant, neoplasm

Cite This Article: Omotayo Ja, Duduyemi Bm, Buhari Mo, and Anjorin As, "Histopathological Pattern of Childhood Solid Tumours in Ilorin: A 28-Year Retrospective Review." American Journal of Medical Sciences and Medicine 1, no. 6 (2013): 105-109. doi: 10.12691/ajmsm-1-6-2.

\section{Introduction}

Childhood cancer is a small fraction of the global cancer burden, yet for children with cancer and their families it can be deeply distressing. ${ }^{1}$ This is especially so in poorer countries, where childhood cancer is often detected too late for effective treatment; where appropriate treatment is often not available and when available not affordable. ${ }^{1}$ In the developing countries, about $60 \%$ of children with cancer die of the disease [1].

Childhood malignant neoplasms account for about 2\% of all cancers, yet they are the second commonest cause of death in children aged 5-14 in populations where overall mortality is low [1]. In affluent countries, about $6 \%$ of childhood deaths are due to cancer, twice the proportion due to infections in those countries [1].

Across the African continent, infectious diseases and malnutrition have long been the primary causes of childhood morbidity and mortality. [2] However, with improved healthcare facilities and extensive national immunization programmes, coupled with generally improving socio-economic status, malignant diseases are beginning to account for a significant percentage of childhood morbidity and mortality [2].

Cancer is a significant paediatric problem in several parts of Africa and the rest of the developing world. Developing countries contribute an estimated $60 \%$ of the total burden of all new cancer cases worldwide. [3] Childhood cancer is rare everywhere in the world. [4] The age-standardized annual incidence usually ranges between 70 and 160 per million at age 0-14 years. [5] Greater variation is seen between populations for some specific tumour types. Some of the largest variations are geographical and are attributable to environmental factors, whereas variation mainly on ethnic lines seems likely to be a marker of genetic predisposition [4].

One child in 500 will develop cancer before the age of 15. [5] Incidence of paediatric malignant neoplasms in 
many developing and developed countries vary from 155 per million persons in Nigeria, [6] to 125 per million in the United States of America [6] and 40 per million persons in the Indian population of Fiji [6].

The low prevalence of paediatric malignancies in many sub-saharan African countries is due to large number of cases that are never seen by a physician. Low index of suspicion and poor diagnostic facilities also contribute to low reported prevalence, late diagnosis and poor survival rates of certain types of childhood cancers [5].

Burkitt's lymphoma is the commonest paediatric malignant tumour seen in various studies in Nigeria [2,3,7-19]. Common childhood malignant neoplasms in other parts of the world include intracranial tumours; neuroblastoma, osteosarcoma, Ewing's sarcoma, and soft tissue sarcoma. [20] Intracranial neoplasms are relatively more common in caucasians. [17-26,31-40] However, the incidence of intracranial tumours is lower in Poland than in other European countries [36] where lymphomas, bone tumours and gonadal tumours are more frequently diagnosed when compared to other European countries.

Certain childhood neoplasms such as nephroblastoma and retinoblastoma apparently originate in the context of aberrant embryogenesis, which is reflected by the striking histological resemblance of these neoplasms to foetal tissues at various stages of development [3].

Since children, the potential workforce of future society, constitute over $40 \%$ of the population in the tropics, childhood cancer produces considerable socio-economic stresses on both the society at large and the immediate family of the afflicted children in particular $[3,26]$.

This is a retrospective review of paediatric solid malignant neoplasm seen in the University of Ilorin Teaching Hospital, Ilorin North Central Nigeria.

\section{Materials and Methods}

The study is a 28 year retrospective study of paediatric malignant solid neoplasms seen in the Department of Morbid Anatomy and Histopathology of the University of Ilorin Teaching Hospital between January 1979 and December 2006.

The surgical biopsy, cytology and post-mortem registers were retrieved and cases of malignant solid neoplasms seen in children between the ages of 0 and 15 within the study period were recorded. The demographic characteristics of all cases that fall within the study group were retrieved from the archives and recorded. The age, sex, site, mode of presentation and diagnosis were recorded against the name and biopsy number. The histopathological, cytological and the post-mortem slides of the recorded cases were retrieved and reviewed. Fresh sections were prepared for faded, broken or lost slides from the paraffin-embedded tissue blocks.

Histochemical staining techniques such as Phosphotungstic acid haematoxylin (PTAH) for myofibrils, Masson's Trichome for collagen, silver impregnation stains for reticulin, Masson-Fontana ammoniac silver stain for melanin and argentaffin granules and other necessary stains were employed where necessary.

Sub-grouping of the various classes of tumours was done based on the World Health Organization (W.H.O.) classifications. Approval for the study was taken from the University of Ilorin Teaching Hospital ethics review board.

\section{Results}

A total of 34,138 surgical biopsy specimens were received in the Department of Morbid Anatomy and Histopathology of the University of Ilorin Teaching Hospital, Ilorin during the 28-year period of this study (January 1979 - December 2006). Out of these, 2,761 surgical biopsy specimens were received from children aged between $0-15$ years. This represented $8.1 \%$ of the total surgical specimens received. Paediatric malignant solid neoplasms accounted for 261 out of the 2,761 surgical biopsy specimens. This represented $0.76 \%$ of the total surgical biopsy specimens received and 9.45\% of surgical biopsy specimens received from children.

One case of malignant thymoma was diagnosed from post-mortem examination of a 10 year old boy. Additional 62 cases of Burkitt's lymphoma were diagnosed from Fine Needle Aspiration Cytology.

A total of 324 cases of paediatric solid malignant neoplasm comprising 261 histologically diagnosed and 62 cytologically diagnosed and 1 from autopsy were thus included into the study. Two hundred and eleven cases $(65.1 \%)$ were seen in males while 113 cases $34.9 \%$ were seen in females, giving a male: female ratio of about 1.9.1. Seventy five cases $(23.1 \%)$ were seen in the $0-4$ year age group, 118 cases (36.4\%) in the 5-9 year age group while 131 cases (40.4\%) were seen in the 10-15 year age group.

The total study population size is 2,365,353 persons. This consists of $50.5 \%$ male and $49.5 \%$ female [41] With about $44 \%$ of Nigerians under the age of 15 years, [42] the total children population in the study area is 1, 040,755. Thus, the prevalence in the studied age group is 311 per million children. During the 28-year study period, a total of 3560 malignant neoplasms were registered of which childhood malignancies accounted for a relative frequency of $9.13 \%$.

Table 1. HISTOLOGICAL TYPES OF SOLID MALIGNANT TUMOURS

\begin{tabular}{|c|c|c|}
\hline HISTOLOGY & NO & \% \\
\hline Lymphoma & 180 & 55.56 \\
\hline Nephroblastoma (Wilms' Tumour) & 27 & 8.33 \\
\hline Retinoblastoma & 25 & 7.72 \\
\hline Osteogenic sarcoma & 10 & 3.09 \\
\hline Fibrosarcoma & 9 & 2.78 \\
\hline Malignant Fibrous Histiocytoma & 2 & 0.62 \\
\hline Dermatofibrosarcoma protuberans & 2 & 0.62 \\
\hline Rhabdomyosarcoma & 12 & 3.70 \\
\hline Carcinoma & 14 & 4.32 \\
\hline Malignant Thymoma & 1 & 0.31 \\
\hline Neuroblastoma & 6 & 1.85 \\
\hline Germ Cell Tumour & 7 & 2.16 \\
\hline Sex Cord-Stromal Tumour & 3 & 0.93 \\
\hline Kaposi sarcoma & 4 & 1.23 \\
\hline Extraosseus Ewing's Sarcoma & 1 & 0.31 \\
\hline Poorly differentiated carcinoma & 8 & 2.47 \\
\hline Metastasis of undetermined pry & 1 & 0.31 \\
\hline Others & 12 & 3.70 \\
\hline Total & 324 & 100.0 \\
\hline
\end{tabular}

Table 1 shows the histological types of the solid malignant tumours seen in this study. Lymphoma was the commonest paediatric solid malignant neoplasm seen in this study and accounted for 180 cases (55.56\%). Nephroblastoma (Wilms' tumour) constituted the second 
largest group with 27 cases (8.33\%). This was followed by retinoblastoma which accounted for 25 cases $(7.72 \%)$. The relative frequency of other malignant neoplasms is as shown in Table 1.

\section{Lymphoma}

One hundred and eighty cases of lymphoma were diagnosed during the study period. These accounted for $55.56 \%$ of all the paediatric malignant solid neoplasms seen in this study. One hundred and twenty-two cases (67.8\%) were seen in males while 58 cases (32.2\%) were seen in females. This gave a male: female ratio of 2.1:1. (Table 2) Nineteen cases (10.6\%) were seen in the $0-4$ year age group, 84 cases (46.7\%) were seen in the 5-9 year age group while 77 cases $(42.8 \%)$ were seen in the 10-15 year age group (Table 3).

One hundred and forty-four cases of Burkitt lymphoma (80\% of all lymphomas) were seen during the study period and constituted the largest group of childhood lymphomas seen in this centre during the study period. Hodgkin's lymphoma accounted for 17 cases (9.4\% of all lymphomas) while other non-Hodgkin's lymphomas accounted for 19 cases. (10.6\% of all lymphomas) (Figure 1$)$.
Table 2. SEX DISTRIBUTION OF SOLID MALIGNANT TUMOURS IN CHILDREN

\begin{tabular}{|c|c|c|c|c|c|}
\hline Histological Type & $\begin{array}{c}\text { Male } \\
\text { No }\end{array}$ & $\mathbf{\%}$ & $\begin{array}{c}\text { Female } \\
\text { No }\end{array}$ & $\begin{array}{c}\text { \% } \\
\text { No }\end{array}$ \\
\hline Lymphoma & 122 & 67.8 & 58 & 32.2 & 180 \\
\hline Nephroblastoma & 15 & 55.6 & 12 & 44.4 & 27 \\
\hline Retinoblastoma & 16 & 64.0 & 9 & 36.0 & 25 \\
\hline Osteogenic sarcoma & 7 & 70.0 & 3 & 30.0 & 10 \\
\hline Rhabdomyosarcoma & 5 & 41.7 & 7 & 58.3 & 12 \\
\hline Neuroblastoma & 4 & 66.7 & 2 & 33.3 & 6 \\
\hline Fibrosarcoma & 6 & 66.7 & 3 & 33.3 & 9 \\
\hline *MFH & 1 & 50.0 & 1 & 50.0 & 2 \\
\hline$* *$ Protuberans & 1 & 50.0 & 1 & 50.0 & 2 \\
\hline Germ Cell tumour & 4 & 57.1 & 3 & 42.9 & 7 \\
\hline $\begin{array}{c}\text { Sex Cord-Stromal } \\
\text { tumour }\end{array}$ & 2 & 66.7 & 1 & 33.3 & 3 \\
\hline Kaposi sarcoma & 3 & 75.0 & 1 & 25.0 & 4 \\
\hline Carcinoma & 9 & 64.3 & 5 & 35.7 & 14 \\
\hline $\begin{array}{c}\text { Poorly diff } \\
\text { Carcinoma }\end{array}$ & 6 & 75.0 & 2 & 25.0 & 8 \\
\hline Metastatic tumour & - & - & 1 & 100.0 & 1 \\
\hline $\begin{array}{c}\text { Extraosseus } \\
\text { Ewing's }\end{array}$ & 1 & 100.0 & - & - & 1 \\
\hline $\begin{array}{c}\text { Malignant } \\
\text { Thymoma }\end{array}$ & 1 & 100.0 & - & - & 1 \\
\hline $\begin{array}{c}\text { Others } \\
\text { TOTAL }\end{array}$ & 211 & 66.7 & 4 & 33.3 & 12 \\
\hline
\end{tabular}

*Malignant Fibrous Histiocytoma, **Dermatofibrosarcoma Protuberans

\begin{tabular}{|c|c|c|c|c|c|c|}
\hline Histological Type & 0-4 yr Age group & $\%$ & 5-9 yr Age group & $\%$ & 10-15 yr Age group & $\%$ \\
\hline Lymphoma & 19 & 10.6 & 84 & 46.7 & 77 & 42.8 \\
\hline Nephroblastoma & 16 & 59.3 & 10 & 37.0 & 1 & 3.7 \\
\hline Retinoblastoma & 22 & 88.0 & 2 & 8.0 & 1 & 4.0 \\
\hline Osteogenic sarcoma & - & - & 1 & 10.0 & 9 & 90 \\
\hline Rhabdomyosarcoma & 3 & 25.0 & 2 & 16.7 & 7 & 58.3 \\
\hline Neuroblastoma & 2 & 33.3 & 2 & 33.3 & 2 & 33.3 \\
\hline Fibrosarcoma & 2 & 22.2 & 2 & 22.2 & 5 & 55.6 \\
\hline MFH & 1 & 50.0 & 1 & 50.0 & - & - \\
\hline D Protuberans & - & - & - & - & 2 & 100.0 \\
\hline Germ Cell Tumour & 2 & 28.6 & 1 & 14.3 & 4 & 57.1 \\
\hline Sex Cord-Stromal Tumour & 1 & 33.3 & 1 & 33.3 & 1 & 33.3 \\
\hline Kaposi sarcoma & 1 & 25.0 & - & - & 3 & 75 \\
\hline Carcinoma & 2 & 14.3 & 4 & 28.6 & 8 & 57.1 \\
\hline Intracranial tumour & 1 & 33.3 & 1 & 33.3 & 1 & 33.3 \\
\hline Extraosseus Ewing's Sarcoma & - & - & 1 & 100.0 & - & - \\
\hline Poorly diff carcinoma & 1 & 12.5 & 3 & 37.5 & 4 & 50.0 \\
\hline Metastatic tumour & - & - & - & - & 1 & 100 \\
\hline Malignant Thymoma & & & & & 1 & 100.0 \\
\hline Others & 3 & 25.0 & 4 & 33.3 & 5 & 41.7 \\
\hline TOTAL & 75 & 23.1 & 118 & 36.4 & 131 & 40.4 \\
\hline
\end{tabular}

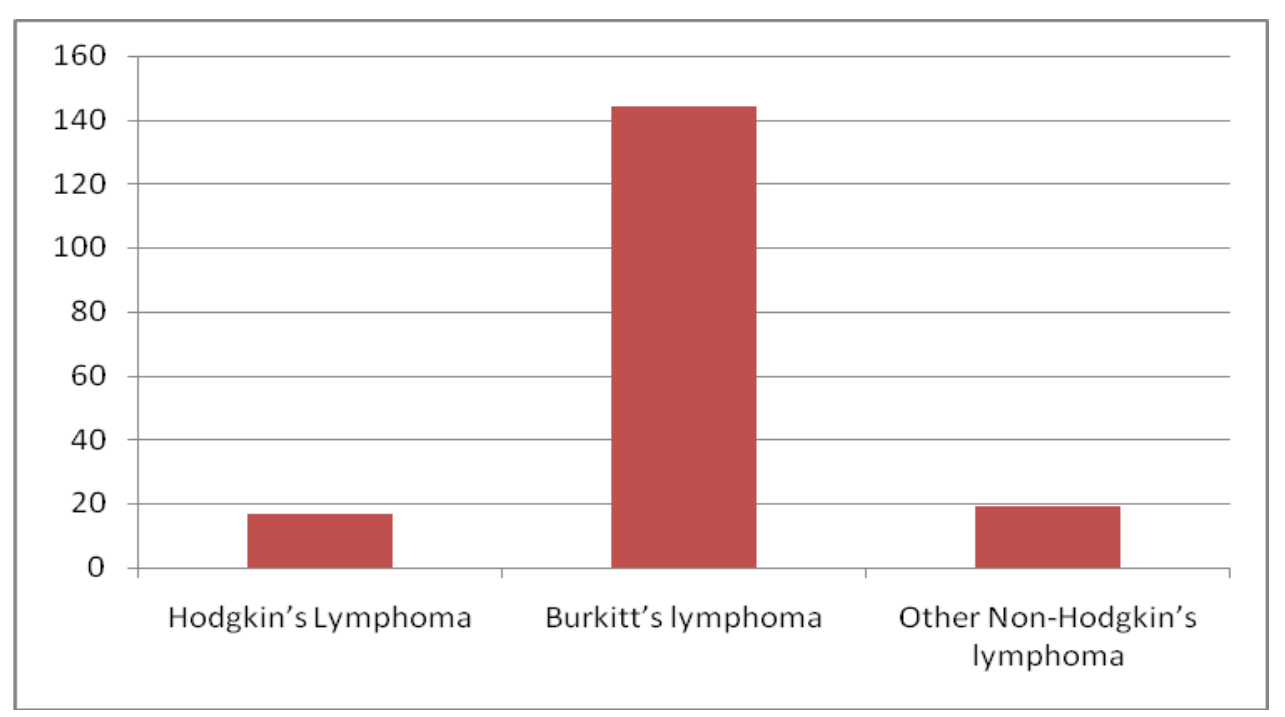

Figure 1. Relative Frequency of the Histological subtypes of childhood lymphoma 


\section{Discussion}

The pattern of childhood malignant solid neoplasms seen in this study compared favourably well with results from Nigeria and other African countries. This pattern is similar to the findings in Ibadan, [3,7,9] Jos, [16] Lagos, [2] Ife, [10] and Western Kenya. [28] Burkitt's lymphoma is the commonest solid malignant tumour of childhood seen in Ibadan, [3,7,9] Ife, [10] Lagos, [2] Ghana and Western Kenya. [28] This is consistent with the findings in this study. There is a male predominance in the cases of lymphoma as a whole and also in the cases of Burkitt's lymphoma which is the general pattern in studies in other parts of the country and the world [2,3,7,9,29-40].

Majority of the cases of lymphoma (89.4\%), were seen between the ages of 5 and 14 years with about $46.7 \%$ occurring in the 5-9 year age group. In Ibadan, majority of the cases were seen between the ages of 5 and 10 years $[3,9]$ with a peak between 6 and 8 years. This is similar to the findings in Jos, [15] Sokoto [19] and Lagos. [2] In Europe, however, Burkitt's lymphoma appears in older children [34-40].

The ratio of the Hodgkin's to Non-Hodgkin's lymphoma in this study is 1:10.6. This falls in the range of 1:4 in Lagos [2] to 1:13.5 in Ibadan. [7] In contrast, the situation in the more developed countries is different where the ratio approaches $1: 1[36,37,38,39,40]$.

Nephroblastoma was the second commonest solid malignant tumour in childhood in this study. This is slightly different from the findings in Lagos, [2] Ibadan, [3,9] and Jos [15] where retinoblastoma occupied the second place. However, the relative frequency in this study compared with those in these other studies. A temporary break of three years (1985-1988) in the ophthalmological services within the hospital may be contributory to the lower number of retinoblastomas seen.

Thirty-nine per cent of nephroblastoma cases presented after the age of 4 years. This fraction is significant as about $80 \%$ of cases are diagnosed before the age of 5 years. The increase in the number of cases diagnosed after the age of 4 years in this study could be as a result of the small sample size. Nephroblastoma is the commonest renal malignant neoplasm seen in this study. This is consistent with existing literature [24,40].

Retinoblastoma has a high incidence in Africa. It is the second commonest solid tumour in Ibadan [7] and Lagos [2] but in this study, it was the third commonest paediatric malignant solid neoplasm In Europe and America, it is less common, accounting for $4.5 \%$ of tumours in Europe, 4.3\% and 4.2\% among American blacks and white respectively [43].

The relative frequency ratio of $7.7 \%$ seen in this study agrees with findings in other parts of Africa. Eighty-eight percent of the patients were below the age of 5 years which closely agrees with the work of Olurin and Williams [7] in Ibadan.

Fibrosarcoma was relatively rare in this study. This is similar to the findings of Williams in Ibadan and O'connor and Davies in Uganda. No case was reported in studies in Jos [15] and Ghana [21].

Malignant bone tumours are relatively common in this study. This is consistent with findings in Jos and Ibadan. This is however in contrast with findings in Uganda. [3,9] Majority of the patients were males in the 10-15 years age group which correlate with the first peak reported in the literature [3,9].

Rhabdomyosarcoma is one of the most common soft tissue sarcoma in the African child and this was reflected in this study. All but 5 of the patients were in the age group of 10-14 years, which contrasts the finding in Ibadan where the peak age incidence was between 2 and 4 years $[3,9]$.

Neuroblastoma, germ cell tumours and epithelial tumour were relatively rare in this study which compares favourably with studies in Ibadan [7], Zaria [18] and Jos [15].

\section{Conclusion}

The pattern of paediatric malignant solid neoplasms seen in Ilorin is similar to the trend in Nigeria and other African countries. Full range surgical and medical oncology expertise is invaluable for optimal care for childhood cancer patients. Histological diagnosis should be obtained before commencement of treatment for these patients.

\section{References}

[1] Mortara I. Preface. In: Childhood cancer. Rising to the challenge. International Union against cancer (UICC) article (www.uicc.org) updated 2006.

[2] Tijani SO, Elesha SO, Banjo AA. Morphological patterns of paediatric solid cancers in Lagos, Nigeria. West Afr J Med. 1995; 14(3):174-180.

[3] Akang EEU. Tumours of childhood in Ibadan, Nigeria. (19731990). Paediatr Pathol Lab Med 1996; 16(5):791-800.

[4] Stiller CA. Epidemiology and genetics of childhood cancer. Oncogene 2004; 23:6429-6444.

[5] Stiller CA. The global problem of Childhood Cancer. Paper presented at the International Society of Paediatric Oncology (ISPO) Workshop, London. May 1996.

[6] Kupfer GM. Childhood Cancer, Epidemiology (e-medicine article www.emedicine.com. updated April 2006).

[7] Ojesina AI, Akang EEU, Ojemakinde KO. Decline in the frequency of Burkitt's lymphoma relative to other childhood malignancies in Ibadan, Nigeria. Ann Trop Paediatr 2002; 22(2): 159-163.

[8] Ayoola OO, Orimadegun AE, Akinsola AK, Osinusi K. A 5 year review of childhood mortality at the University College Hospital, Ibadan. West Afr J Med 2005 Apr-Jun; 24(2): 175-179.

[9] Williams AO. Tumours of childhood in Ibadan, Nigeria. Cancer. 1975; 36(2): 370-378.

[10] Adelusola KA, Odesanmi WO, Adejuyigbe O, Rufai OA, Durosinmi MA, Akinola NO. Malignant solid tumours in Nigerian children. Cent Afr J Med. 1995; 41(10):322-326.

[11] Obioha FI, Kaine WN, Ikerionwu SE, Obi GO, Ulasi TO. The pattern of childhood malignancy in Eastern Nigeria. Ann Trop Paediatr. 1989 Dec; 9(4):261-265.

[12] Onwasigwe CN, Aniebue PN, Ndu AC. Spectrum of paediatric malignancies in Eastern Nigeria 1989-1998. West Afr J Med. 2002; 21(1): 31-33.

[13] Ocheni S, Okafor CO, Emodi IJ et al. Spectrum of childhood malignancies in Enugu, Nigeria (1999-2004). Afr J Med Sci. 2005 Dec; 34(4): 371-375.

[14] Ekanem IA, Asindi AA, Ekwere PD, Ikpatt NW, Khalil MI. Malignant Childhood tumours in Calabar, Nigeria. Afr J Med Sci 1992; 21(2): 63-69.

[15] Mandong BM, Angyo JA, Zoakah AI. Paediatric solid malignant tumours in JUTH, Jos, Nigeria. (Hospital based Histopathology study). Nig J Med. 2000; 9(2):52-55.

[16] Tanko NM, Echejoh GO, Manasseh NA, Mandong BM, Uba AF. Paediatric solid tumours in Nigeria: A changing pattern? Afr J Paediatr Surg. 2009; 6: 7-10. 
[17] Akinyinka OO, Falade AG, Ogunbiyi JO, Johnson AOK. Hepatocellular Carcinoma in Nigerian Children. Ann Trop Paediatr. 2001 June 21(2): 165-8.

[18] Aikhionbare HA, Yakubu AM, Afolayan EA. Neuroblastoma, an under-diagnosed tumour: a 7-year experience in Zaria. Ann Trop Paediatr. 1988 Sep; 8(3): 149-152.

[19] Malami SA, Dauda AM, Pindiga UH, Abimiku BA, Abubakar DA. A Pathology frequency study of childhood solid cancer in Sokoto. Sahel Med J. 2005; 8(4): 106-109.

[20] Crist WM, Kun LE. Common solid tumours of childhood. N Eng J Med.1991; 324(7): 461-468.

[21] Welbeck JE, Hesse AA. Pattern of childhood malignancy in Korle Bu Teaching Hospital, Accra, Ghana. West Afr J Med 1998; 17(2): 81-84.

[22] Koulibaly et al. Cancer incidence in Conakry, Guinea: First results from the Cancer registry 1992-1995. Int J Cancer 1997; 70: 39-45.

[23] Elatter I. Cancer Statistics. Report of the National Cancer Institute (NCI) in Egypt, 2002-2005.

[24] Paulino AC, Coppes MJ. Wilms' Tumour (e-medicine article www.emedicine.com. updated March 2009).

[25] Rose LJ, Fishman AD, Sparano JA. Kaposi Sarcoma (e-medicine article www.emedicine.com. updated August 2008).

[26] Akang EEU. Epidemiology of cancer in Ibadan: tumours in childhood. Arc Ibadan Med April 2000; 1(2): 9.

[27] Teka T. Childhood malignancies in an Ethiopian Teaching Hospital. Ethiop Med J 1992 Jul; 30(3): 159-62.

[28] Makata AM, Toriyama K, Kamidigo NO, Eto H, Itakura H. The pattern of Paediatric solid malignant tumours in Western Kenya, 1979-1994: An analysis based on histopathological study. Am J Trop Med Hyg. 1996; 54(4): 343-347.

[29] Patil PS, Elem B, Gwavava NJ, Urban MI. The pattern of paediatric malignancy in Zambia, 1980-1989: a hospital based histopathology study. J Trop Med Hyg. 1992; 95(2): 124-127.

[30] Hesseling PB, Wessels G, van Riet FA. The Tygerberg Hospital Children's Tumour Registry 1983-1993. Eur J Cancer. 1995; 31A(9): 1471-1475.
[31] Chaudhuri K, Sinha A, Hati GC, Karmakar R, Banerjee A. Childhood malignancies at BS Medical College: a ten year study. Indian J Pathol Microbiol. 2003; 46(2): 194-196.

[32] Patil K, Malima VG, Jayanth BS, Ambika L. Burkitt’s Lymphoma in an Indian girl: A case report. J Indian Soc Pedod Prev Dent. 2007; 25:194-199.

[33] Moy TA, Ha C. First report of the Singapore Cancer Registry. (1997-2005).

[34] Li CK, Mang OWK, Foo W. Epidemiology of Paediatric cancers in Hong Kong, 1982-1991. Hong Kong Med J.1999; 5(2):128-134.

[35] Ajiki W, Hanai A, Tsukuma H, Hivama T, Fujimoto I. Incidence of childhood cancers in Osaka, Japan. 1971-1988: reclassification of registered cases by Birch's Scheme using information on clinical diagnosis, histology and primary site. Jpn J Cancer Res. 1994; 85(2): 139-46.

[36] Jakab Z, Balogh E, Kiss C, Olah E Epidemiological studies in a population-based childhood cancer registry in Northeast Hungary. Med Paediatr Oncol. 2002; 38(5): 338-344.

[37] Plesko I, Somogyi J, Dimitrova E. Incidence of childhood tumours in Slovakia. Neoplasma. 1983; 30(6): 733-742.

[38] Dreifaldt AC, Carlberg M, Hardell L. Increasing incidence rates of childhood malignant diseases in Sweden during the period 19601998. Eur J Cancer 2004; 40: 1351-1360.

[39] Desandes E, Clavel J, Berger C et al. Cancer incidence among children in France, 1990-1999. Paediatric Blood \& Cancer. 2004; 43(7): 749-757.

[40] Kowalczyk JR, Dudkiewicz E, Balwierrz W, BoguslawskaJaworska J, Rokicka-Milewska R. Incidence of childhood cancers in Poland in 1995-1999. Med Sci Monit, 2002; 8(8): 587-590.

[41] Federal Republic of Nigeria. Official Gazette. 2009 Feb; 96(2): B34.

[42] Federal Republic of Nigeria. National Policy on Population for Sustainable Development. 2004 January; 1.

[43] Ajaiyeoba IA, Akang EEU, Campbell OB et al. Retinoblastomas in Ibadan: treatment and prognosis. West Afr J Med.1993; 12: 223-227. 